\title{
Harmonic Tourism Theoretical and Methodological Model: Application to the Central Highlands of Mexico
}

\author{
By Daniela Palmas Castrejón* \\ Rocio Serrano-Barquín ${ }^{\dagger}$ \\ Jesús Gastón Gutiérrez Cedillo ${ }^{*}$
}

The aim of this paper is to present a case of the application of the Theoretical and Methodological Model for Harmonic Tourism, proposed by Palmas et al, (2014), in order to carry out tourism-based planning tasks through the interaction of communities with both vernacular and rational knowledge, which allows for the analysis and management of harmonic tourism as an alternative to sustainable local development. The methodology applied begins with the theoretical and methodological supports that take into account some analysis categories, such as hommo-ecosystem, systemic elements and sub-elements, harmonic tourism, as well as vernacular and rational knowledge. These categories allow integration from a diagram of vernacular-rational touristic planning with the relevant relationships between biophysical and anthropic subsystems about the use of natural and cultural resources. In order to achieve this goal, 374 questionnaires were randomly distributed, as well as 45 in-depth interviews with key actors, visits and continuous field observations, throughout a period of 4 years (2009-2013). The proposed model was applied in San Pedro Tultepec, which includes the Chimaliapan Lagoon, in the municipality of Lerma, State of Mexico, Mexico. The main results include identification and explanation of environmental problems from the perspective of complex systems, consideration of harmonic tourism as a tool to promote local development, and the importance of spreading of information, regarding the tangible and intangible services offered by the Lagoon to the community in order to promote awareness about the rescue of their current resources.

Keywords: Harmonic tourism, hommo-ecosystem, San Pedro Tultepec de Quiroga, sustainable local development, vernacular-rational knowledge.

\section{Introduction}

Tourism in Mexico plays an important role as the third generating sector of income. In 2013, international tourism increased 1.9\%, according to the report of the Panorama of the Tourist Activity in Mexico (CNET 2014), yielding a balance of 3,682.4 million dollars, an 11.1\% increase from the amount in 2012. The main visitors coming to Mexico are from the United States $(8.9 \%)$, the United Kingdom (18\%), Colombia (58.4\%), Argentina (4.9\%), and Brazil (5.4\%)

\footnotetext{
*Professor, Autonomy University of Estado, Mexico. ${ }^{\dagger}$ Professor, Autonomy University of Estado, Mexico.

${ }^{\star}$ Professor, Autonomy University of Estado, Mexico.
} 
These data confirm that tourism is a solid source of income for the country. It is desirable for the tourism to be harmonic in the places where this activity is realized. If it is well organized, it can be a complement for communities' development, for the rescue of their own identity and for natural resources that are in danger. Such is the case of environmental transformations, particularly the loss of biodiversity, the overexploitation of natural resources, and the pollution of soil and water (Serrano-Barquín 2008, SEMARNAT 2010), which have caused not only imbalance in the biophysical subsystem, but also negative impacts in the anthropic system by changing the daily life of the inhabitants in communities like those located inside Natural Protected Areas or close to bodies of water. This is the case of those located in Lerma, State of Mexico.

The State of Mexico is one of five states with a greater surface of protected areas in the country (SEMARNAT 2003); however, the processes of industrialization and urbanization in this region have generated solid wastes. The extraction of water to supply Mexico City and other urban zones, the deforestation of closer mountains, and changes of soil uses, among others, are affecting the harmony of the biophysical subsystem. This situation constitutes an emergency call supported with tasks that allow nature not only to be taken into account, but also to be used by future generations. This is the aim of sustainability (OMT 2002).

In 2010 , the population of the state was $15,175,872$ inhabitants, with a greater location in the Valley of Mexico and Toluca metropolitan zones (INEGI 2010); this spatial imbalance causes an increase in unemployment of closer rural communities, affecting health, loss of identity, lack of family bonds, and a decrease in agricultural production.

In order to face this situation, research was conducted and developed in two stages: analysis and proposal. The first one was achieved by philosophical theoretical and epistemological reflection, as well as review of relevant sources regarding methods to support an interdisciplinary and dialectic approach (Palmas et al. 2011). The second stage took into account the instruments addressed to know the reality, to build an anthropic subsystem model, keeping a constant link between theory and practice, as well as simultaneosly biophysical and anthropic subsystems, by means of harmonic tourism, in order to encourage local development based on vernacular and rational knowledge. (Palmas et al 2014)

The model was applied to a community, giving rise to this document, where the links between theory and reality are shown; this was the community of San Pedro Tultepec de Quiroga and the Chimaliapan Lagoon, located in the municipality of Lerma, State of Mexico.

\section{Literature Review}

\section{Hommo-Ecosystem, Harmonic Tourism and Vernacular-Rational Knowledge}

The concept of hommo-ecosystem (Serrano-Barquín 2008, Palmas et al. 2014) is defined as a complex system, in which harmonic tourism is able to integrate 
and link with other areas of society; sustainability is held as a principle that favours the permanence of the subsystems that integrate it (biophysical and anthropic), which are continuously and adaptably linked.

The hommo-ecosystem is analyzed in three process levels (micro, intermediate and macro), relating one to the other, so that the system is also studied in four analysis levels (municipal, local, national and international), including the resources of each spatial scale to encourage their development (García 2006). To make the analysis more concrete, they are divided into two subsystems, the biophysical, where soil, weather, water bodies, flora and fauna, among others, are integrated; and the anthropic one, which systematically includes social, cultural and economic features, among others. Each of the elements that systematically integrate the subsystems interacts among them, without losing their specific properties.

Another linking concept is harmonic tourism, considered an integrative multidisiciplinary approach that combines vernacular and rational knowledges, thus articulating the biophysical subsystem with the anthrophic one, in order to encourage sustainable local develoment in communities that show interest in recovering, maintaining and preserving the surrounding natural and cultural resources.

The vision of sustainability is an ideology that should be involved with communities interested in linking nature, human capital, culture, society, manufacturing processes, and the economy, among others (Norgaard 1995, Blázquez 2011). Therefore, harmonic tourism can be used in any tourism task, since it is an integrative activity that provides social and economic benefits. For instance, it generates jobs and income by improving the life of both communities and tourism. Another feature of this type of tourism is that it improves the resistance of the biophysical subsystem and its processes (Serrano-Barquín 2008)

To support the previous concepts, the following concepts regarding complex thought must be analyzed and applied (Morin 2005): the dialogical principle considers harmonic tourism as a concept able to be applied to all types of tourism as an integrative activity, linked with others that are already performed in a region, in order to consolidate diversity of actions. On the other hand, the resource principle enables us to understand that harmonic tourism can generate products or services derived from the relationship between vernacular and rational knowledge at different space and time levels. The hologramatic principle (Morin 2005) he states that the whole is in a certain way included (engrammed) in the part that is included in the whole, relates the biophysical and anthropic subsystems in order to rescue and preserve harmony between them.

Under this approach, vernacular and rational knowledge play fundamental roles. The vernacular knowledge is based on traditions, intuition and knowledge inherited by a generation. The rational knowledge comes from the scientific field. When comprising the interrelationship of both, the vernacular-rational use of natural and cultural resources by communities is achieved. 


\section{Methodology}

The methodology of this research was supported by the methodological and theoretical model proposed by Palmas et al. (2014) from the following theoretical suppositions: hommo-ecosystem, harmonic tourism and vernacularrational knowledge, as already defined.

Figure 1 shows the integration of hommo-ecosystem along with its space and temporary delimitation. Harmonic tourism is in the middle acting as an axis between the subsystems and allowing local sustainable development. The base is the biophysical subsystem that emphasizes the impacts on the anthropic subsystem.

In the first level (local), the biophysical and anthropic subsystems of the community are analyzed, both inside and outside. The regional level influences the local level, determined by plans, programs, laws, decrees and projects, among others, which have an impact on decisions and actions that will take place. The national and international level interferes with the local and regional levels, by analyzing the influence of international organisms, non-governmental organizations, agreements, treaties, tendencies and negative impacts over natural, social and cultural resources.

Figure 1. Integration and Analysis of the Hommo-Ecosystem

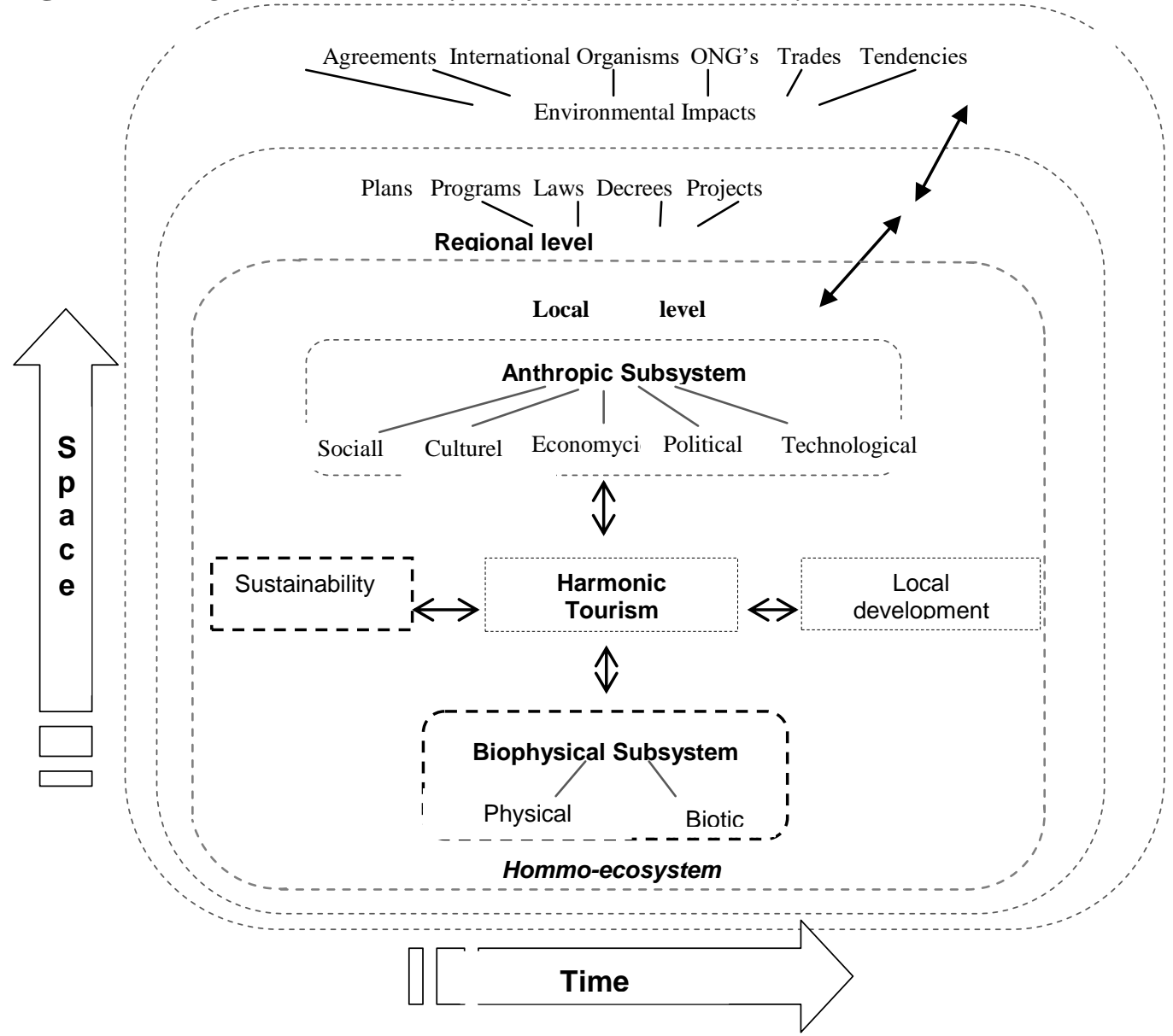

Source: It was designed based on García (2006), Serrano-Barquín (2008) and Segrado et. al (2010). 
To attain the interrelationship of vernacular and rational knowledge regarding natural, social and cultural resources, Table 1 shows the way subsystems work together, including systemic elements and sub-elements, along with sustainability attributes established to analyse such sub-elements in order to keep sustainability as the axis of analysis. Other interrelationships depend on the aim of the research, the object of study and the researcher.

Table 1. Characterization and Diagnosis of the Hommo-Ecosystem

\begin{tabular}{|c|c|c|c|c|c|}
\hline $\begin{array}{l}\text { Sub- } \\
\text { System }\end{array}$ & $\begin{array}{l}\text { Systemic } \\
\text { Elements }\end{array}$ & $\begin{array}{c}\text { Sub-element } \\
\text { Systemic }\end{array}$ & $\begin{array}{c}\text { Attribute of } \\
\text { Sustainability }\end{array}$ & $\begin{array}{l}\text { Rational } \\
\text { Evidence }\end{array}$ & $\begin{array}{l}\text { Vernacular } \\
\text { Evidence }\end{array}$ \\
\hline \multirow[b]{7}{*}{ 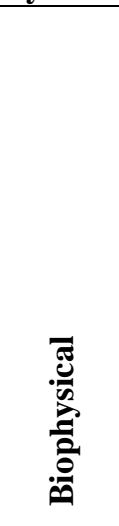 } & \multirow{5}{*}{ Physical } & $\begin{array}{l}\text { Geological } \\
\text { Substrate }\end{array}$ & \multirow{7}{*}{$\begin{array}{c}\text { Resilience } \\
\text { Adaptability } \\
\text { Steadiness }\end{array}$} & \multirow{7}{*}{$\begin{array}{l}\text { References } \\
\text { about: } \\
\text { Soil } \\
\text { properties, } \\
\text { fertility, self- } \\
\text { sufficience } \\
\text { food, rational } \\
\text { use of natural } \\
\text { resources: } \\
\text { soil, water, } \\
\text { pastureland, } \\
\text { agrodiversity, } \\
\text { among others. }\end{array}$} & \multirow{23}{*}{$\begin{array}{l}\text { Observation } \\
\text { and field } \\
\text { diary, life } \\
\text { stories, } \\
\text { interviews and } \\
\text { questionnaires } \\
\text { in order to get } \\
\text { inherited data. }\end{array}$} \\
\hline & & Geo-forms & & & \\
\hline & & Weather & & & \\
\hline & & Hydrology & & & \\
\hline & & Soil & & & \\
\hline & & Fauna & & & \\
\hline & Biotic & Flora & & & \\
\hline \multirow{16}{*}{ 葛 } & \multirow{3}{*}{ Social } & Population & \multirow{11}{*}{$\begin{array}{c}\text { Productiveness } \\
\text { Profitability } \\
\text { Viability }\end{array}$} & \multirow{16}{*}{$\begin{array}{c}\text { Review about: } \\
\text { Architecture } \\
\text { with } \\
\text { bioclimatic } \\
\text { solutions } \\
\text { (adobe, } \\
\text { temples), } \\
\text { participation } \\
\text { of the } \\
\text { community } \\
\text { and meetings, } \\
\text { among others. }\end{array}$} & \\
\hline & & Education & & & \\
\hline & & Facilities & & & \\
\hline & \multirow{3}{*}{ Cultural } & Identity & & & \\
\hline & & Gastronomy & & & \\
\hline & & $\begin{array}{l}\text { Customs and } \\
\text { traditions }\end{array}$ & & & \\
\hline & \multirow{4}{*}{ Economic } & Agriculture & & & \\
\hline & & Cattle raising & & & \\
\hline & & Craft & & & \\
\hline & & Tourism & & & \\
\hline & \multirow{2}{*}{ Technological } & $\begin{array}{c}\text { Current } \\
\text { technology }\end{array}$ & & & \\
\hline & & $\begin{array}{l}\text { Roosted } \\
\text { technology }\end{array}$ & \multirow{5}{*}{$\begin{array}{c}\text { Technological } \\
\text { adaptability }\end{array}$} & & \\
\hline & \multirow{4}{*}{ Political } & $\begin{array}{l}\text { Governmental } \\
\text { organizations }\end{array}$ & & & \\
\hline & & $\begin{array}{c}\text { Private } \\
\text { organizations }\end{array}$ & & & \\
\hline & & Comissions & & & \\
\hline & & Comittees & & & \\
\hline
\end{tabular}

Source: Author.

Note: The interpretation was generated based on data obtained from the interrelation of both types of evidence.

As part of the methodological proposal, depending on each attribute of the studied subsystem, data obtained were related to both types of knowledge. Harmonic tourism highlights the importance of knowledge from communities and specialists. 
The diagram below shows the form in which the main problems were analyzed and how the interrelationships relevant for hommo-ecosystem were detected. Those relationships facilitated the linking of systemic elements and provided answers to the target problem (Figure 2). The different thicknesses of the margin arrows make visible the elements and problematics of greater importance in the interrelationships. To obtain this data, 274 questionnaires were randomly applied, as well as 45 in-depth interviews with key actors, from the knowledge considered in Table 1; visits and field observation were also carried out over a four-year period. (2009-2013). Data were coded and analyzed at San Pedro Tultepec de Quiroga.

Figure 2. Vernacular-Rational Touristic Planning Diagram

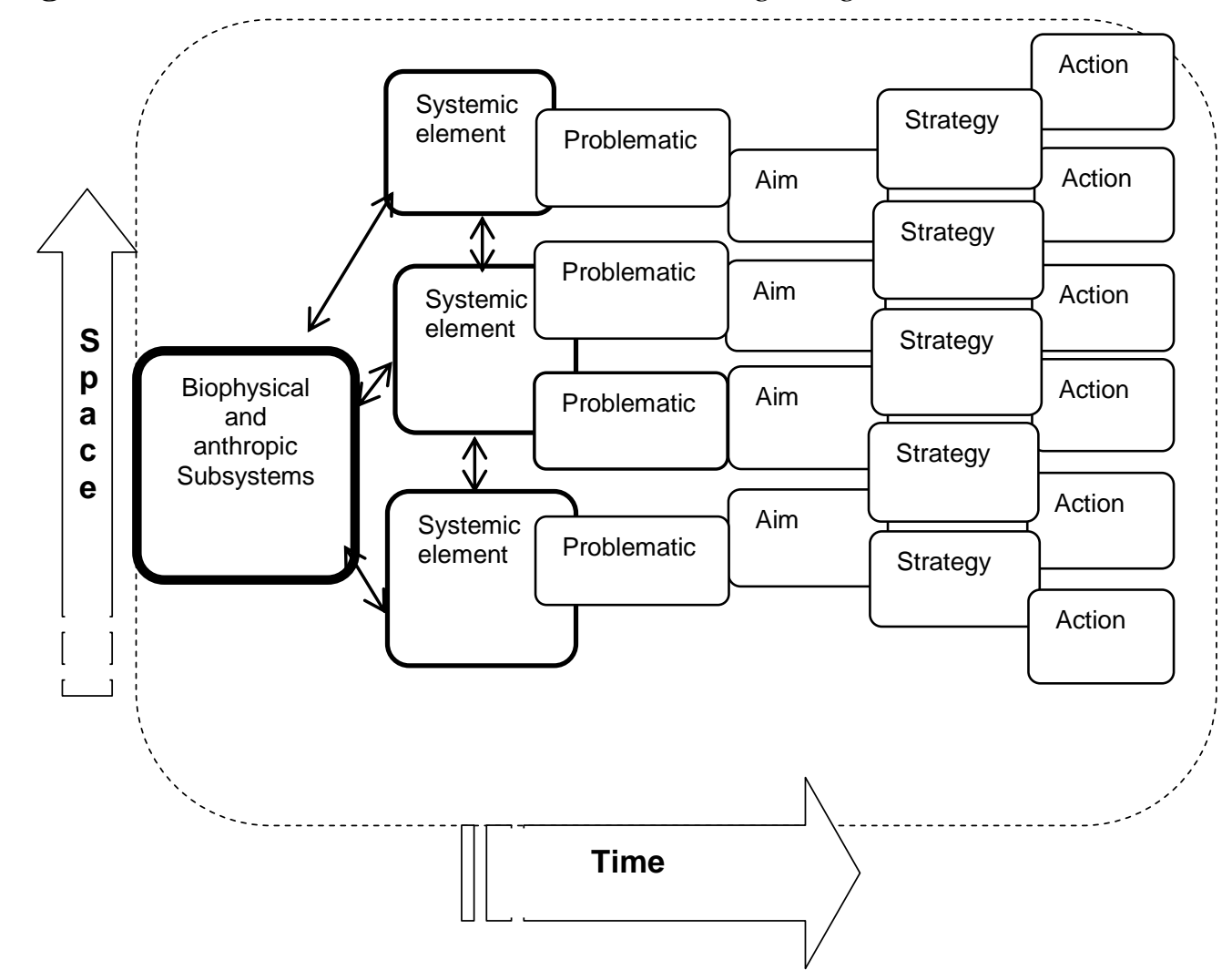

Source: It was designed mean by theoretical and methodological critical analysis Location.

San Pedro Tultepec de Quiroga comes from the Nahuatl which means "In the hill of Tule". It is located $54 \mathrm{~km}$ west of Mexico City and $10 \mathrm{~km}$ east of Toluca City in the Central Highlands of Mexico (Figure 3). It is located in the municipality of Lerma, State of Mexico, with a territorial extension of $228.64 \mathrm{~km}^{2}$ and a population of 13, 634 inhabitants (INEGI 2010). 
Figure 3. Location of San Pedro Tultepec de Quiroga, in Context of the State and the Country of Mexico

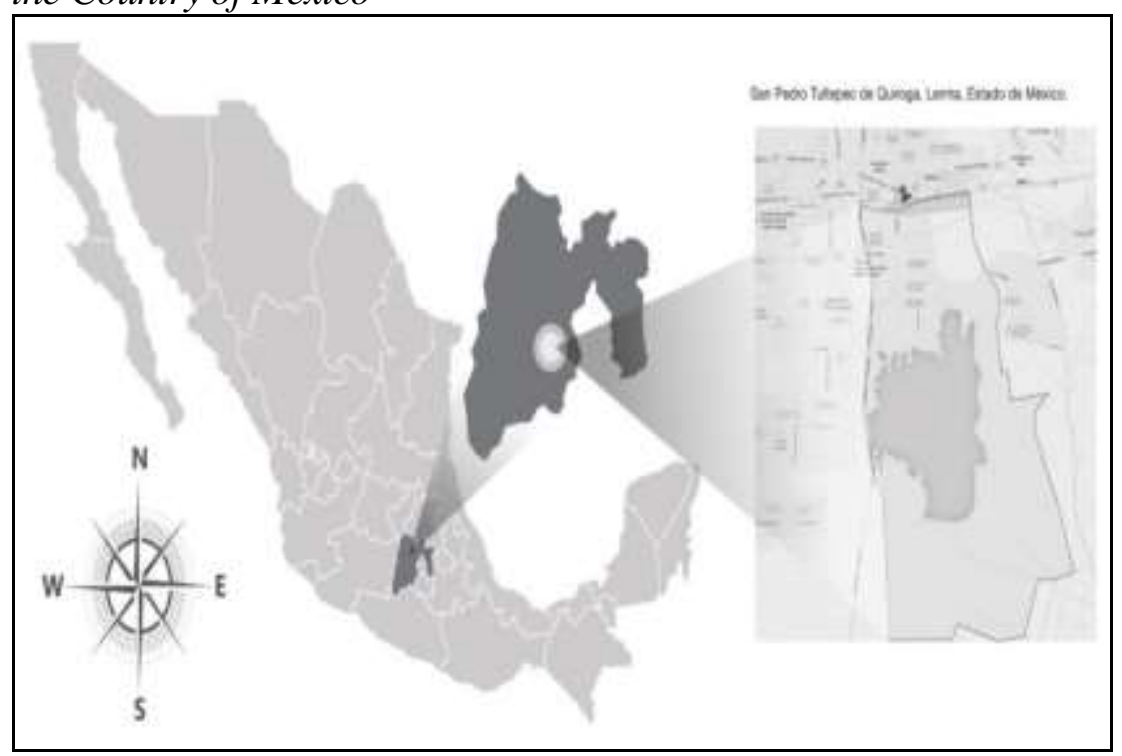

Source: It was designed based on INEGI, 2010

It is very important to consider that this town is located inside a federal Natural Protected Area (NPA), which is called the Flora and Fauna Protection Area of Cuatro Ciénegas Lerma; the NPA is part of the municipalities Almoloya del Río, Capulhuac, Lerma, Metepec, San Mateo Atenco, Texcalyacac and Tianguistenco (CONANP 2011). The Cuatro Ciénegas includes three water bodies separated and interconnected, covering a total area of $30.23 \mathrm{~km}^{2}$. It is also part of a great ecological wetland, which includes Chiconahuapan or Almoloya $\left(5.96 \mathrm{~km}^{2}\right)$, Chimaliapan or Lerma $\left(20.81 \mathrm{~km}^{2}\right)$ and Chignahuapan or Atarasquillo $\left(3.46 \mathrm{~km}^{2}\right)$ Lagoons (Ramsar 2007). The main environmental challenge of these wetlands is that they were included in a project of desiccation for providing water supply to the central region of Mexico from 1942 to 1970 (Albores 1995).

Once the place was contextualized in accordance with methodology, the next step was to characterize the biophysical subsystem (Lagoon of Chimaliapan) and the anthropogenic one (San Pedro Tultepec de Quiroga) on a spatial scale, considering the coevolution of the subsystems from the start of the drying project to the year 2014. These criteria were established because the local population and the scientific community have become aware of major changes in the lagoon affecting the life that used to be in the lake (Tables 2 and 3 ). 
Table 2. Characterization of the Biophysical Subsystem Chimaliapan Lagoon

\begin{tabular}{|l|l|c|}
\hline $\begin{array}{l}\text { Systemic } \\
\text { Elements }\end{array}$ & \multicolumn{1}{|c|}{ Systemic sub-element } & $\begin{array}{c}\text { Attribute of } \\
\text { sustainability }\end{array}$ \\
\hline \multirow{4}{*}{ Physical } & Area of volcanic activity (andesite, basalt, pyroclastic flows) & \\
\cline { 2 - 2 } & Erosion processes have marked natural drainage & \\
\cline { 2 - 2 } & Semi-cold climate, corresponds to C (E) (W2) (W) & \\
\cline { 2 - 2 } & Hydrology: Lerma river, Almoloya del Río springs & \multirow{3}{*}{ Resilience } \\
\cline { 2 - 2 } & Soil: feozem, andosol, inceptisols and mollisols & Adaptability \\
& $\begin{array}{l}\text { Flora: oyamel and some shrubs. } \\
\text { Bake vegetation partially emerged (helofites). }\end{array}$ & \\
& $\begin{array}{l}\text { Floristic richness of 97 species of vascular plants, included } \\
\text { 39 botanic families and 65 genres. }\end{array}$ & \\
\cline { 2 - 2 } & $\begin{array}{l}\text { Endemic and aquatic birds (Notropis sallei, Chirostoma } \\
\text { riojai and Girardinichthys multiradiatus). Approximately }\end{array}$ & \\
& $\begin{array}{l}\text { 18 hunting birds and 23 singing and ornamental (water } \\
\text { hen, coot, tepalcate ducks, baker, bucket and dew). }\end{array}$ & \\
\hline
\end{tabular}

Source: It was designed based on García (2006), (INEGI, 2010), Ceballos (2003), Albores (1995).

Table 3. Characterization of the Anthropic Sub-system of the Hommo-ecosystem San Pedro Tultepec de Quiroga

\begin{tabular}{|c|c|c|}
\hline $\begin{array}{l}\text { Systemic } \\
\text { Elements }\end{array}$ & Systemic Sub-element & $\begin{array}{c}\text { Attribute of } \\
\text { Sustainability }\end{array}$ \\
\hline \multirow{3}{*}{ Social } & 13,634 inhabitant & \multirow{5}{*}{$\begin{array}{l}\text { Equity } \\
\text { Self-management } \\
\text { Self-organization }\end{array}$} \\
\hline & \begin{tabular}{|l} 
The scholar average is eight degree \\
\end{tabular} & \\
\hline & Sub-urbanized zone & \\
\hline \multirow{4}{*}{ Cultural } & $\begin{array}{l}\text { Identity characterized by the way of life of rivers } \\
\text { inhabitants }\end{array}$ & \\
\hline & $\begin{array}{l}\text { Gastronomy: ducks, birds, fish, acociles, frogs, } \\
\text { potatos, sweet beans and huazontles }\end{array}$ & \\
\hline & $\begin{array}{l}\text { Music: bands } \\
\text { Dance of the cuentepecos and the shepherdesses } \\
\text { Religious holidays (New year, Easter week, } \\
\text { "Candelaria", Saint Peter and Saint Paul) }\end{array}$ & \multirow[t]{2}{*}{ Adaptability } \\
\hline & $\begin{array}{l}\text { Tourist attractions: religious and civil architecture, } \\
\text { handicrafts, wood furnishing; myths and legends (The } \\
\text { Witch, The "Nahual", La "Llorona", Black Peter and } \\
\text { the little mermaid) }\end{array}$ & \\
\hline \multirow[t]{4}{*}{ Economic } & $\begin{array}{l}\text { Agriculture: species of vegetables (sweet bean, pea, } \\
\text { potato, pumpkin, "chilacayote", onion, "cilantro", } \\
\text { parsley, cabbage, radish, "arvejon", "ejote”, } \\
\text { cauliflower, turnip), grains (corn, beans and oats), } \\
\text { fruit ("crabapple", "capulin", pear, apple, plum, } \\
\text { walnut, prickly pear, peaches, yellow apple and } \\
\text { kitschy), "agave pulquero", "quelites" ("quintonil", } \\
\text { "huauzontle" and purslane), fodder, flowers and } \\
\text { medicinal plants }\end{array}$ & \multirow[t]{4}{*}{$\begin{array}{l}\text { Productivity } \\
\text { Profitability } \\
\text { Viability }\end{array}$} \\
\hline & Cattle: lambs & \\
\hline & Crafts: Made of tule and wood furniture & \\
\hline & $\begin{array}{l}\text { Roads: } \\
\text { 1. Toluca-Mexico highway, close to Santiago de } \\
\text { Lerma, after the Bicentenario highway } \\
\text { 2. Old route of San Mateo Atenco-San Pedro } \\
\text { Tultepec } \\
\text { 3. Old route of Ocoyoacac-San Pedro Tultepec }\end{array}$ & \\
\hline
\end{tabular}




\begin{tabular}{|c|c|c|}
\hline & 4. Lerma-Tenango-Tres Marías highway & \multirow{6}{*}{$\begin{array}{l}\text { Institutional } \\
\text { viability }\end{array}$} \\
\hline \multirow[t]{2}{*}{ Technological } & $\begin{array}{l}\text { Main technology: fishing with different tools (eliptic } \\
\text { network, fisga o garrocha, among others) } \\
\text { Hunting for food: use of tools like honda and } \\
\text { shotgun. }\end{array}$ & \\
\hline & $\begin{array}{l}\text { Around } 271 \text { houses }(11.4 \%) \text { have a computer, } 1,201 \\
(50.4 \%) \text { have a washing machine and 2,233 (93.7\%) } \\
\text { have a television set }\end{array}$ & \\
\hline \multirow{3}{*}{ Political } & $\begin{array}{l}\text { Governmental organizations: Fondo de Cultura } \\
\text { Económica (FCE) has implemented programs to } \\
\text { promote and rescue crafts } \\
\text { Comisión Nacional de Acuacultura y Pesca: Program } \\
\text { CONAPO of marginality } \\
\text { SAGARPA: Program PROCAMPO, which each year } \\
\text { gives economic support, as a part of the federal } \\
\text { resources for rural tasks }\end{array}$ & \\
\hline & $\begin{array}{l}\text { Private organizations: Agreement about the Swamps. } \\
\text { (Ramsar, 1971), internationally relevant } \\
\text { Civil Association Comunidades del Alto Lerma } \\
\text { (COMALAC) } \\
\text { RET Group and Millihuacán Group }\end{array}$ & \\
\hline & $\begin{array}{l}\text { The soil commission is composed by } 1,500 \text { members, } \\
\text { distributed among } 300 \text { land owners. }\end{array}$ & \\
\hline
\end{tabular}

Source: It was designed considering García (2006), INEGI (2010), Ceballos (2003), Albores (1995).

\section{Results}

From the schematic characterization of the system and considering different axes, such as the analysis of the attributes of environmental, social, cultural, economic, technological and political-institutional sustainability, that prevail in the hommo-ecosystem, the diagnosis took into account both the rational and the vernacular evidence, giving rise to a diagnosis based on the knowledge interrelationship as expressed in Tables 4, 5, 6, 7, 8 and 9. 
Table 4. Diagnosis of the Sub-system Chimaliapan Lagoon, based on attributes of Ecological Sustainability

\begin{tabular}{|c|c|c|}
\hline $\begin{array}{l}\text { Attribute of } \\
\text { Sustainability }\end{array}$ & Rational Evidence & Vernacular Evidence \\
\hline $\begin{array}{l}\text { Steadiness } \\
\text { Resilience } \\
\text { Adaptability }\end{array}$ & $\begin{array}{l}\text { Irregular territory in the central } \\
\text { part of the Toluca-Lerma Valley, } \\
\text { with hillsides and mountains; } \\
\text { fertile land } \\
\text { The soils are vertisol, andosol, } \\
\text { chromiprofondic and feozem. } \\
\text { Regarding land use, the main } \\
\text { activity is agriculture with } 9,356 \\
\text { ha, divided in } 1,867 \text { ha for } \\
\text { fishing; } 5,104 \text { ha of forests; } \\
\text { 1,015 ha for industry; } 1,322 \text { ha } \\
\text { of bodies of water and } 149 \text { ha of } \\
\text { land } \\
\text { Fishing was an important } \\
\text { economic activity that covered } \\
\text { the basic domestic needs, until } \\
\text { the end of the XIX century and } \\
\text { the middle of the twentieth. } \\
\text { In regards to the flora, there are } \\
\text { 19 orders, } 31 \text { families, } 58 \text { genres } \\
\text { and } 68 \text { species; there are } \\
\text { currently } 12 \text { orders, } 16 \text { families, } \\
30 \text { genres and } 42 \text { species of } \\
\text { fauna. } \\
\text { The ANP maintains a regional } \\
\text { biodiversity, approximately } \\
\text { more than } 300 \text { species of plants } \\
\text { and vertebrates, } 72 \text { types of } \\
\text { birds have been recorded } \\
\text { (CONANP } 2011 \text { ). Around } \\
30.000 \text { and } 100.000 \text { migratory } \\
\text { birds arrive there, depending on } \\
\text { the month and year. } \\
\text { In the mountain belt conifers, } \\
\text { deciduous trees, fungi, rabbits, } \\
\text { hares, deer, foxes, wild cats, } \\
\text { wolves and coyotes were } \\
\text { common. } \\
\text { The quality of the water, } \\
\text { according to the Ramsar } \\
\text { information, shows that the }\end{array}$ & $\begin{array}{l}\text { In an interview, Mr. Lechuga (aged 49) } \\
\text { mentioned that he remembered that the } \\
\text { lagoon was so big that he preferred to } \\
\text { grow potatoes. He said "everything we } \\
\text { knew did not rot was fed through natural } \\
\text { herbs, there were not many houses but } \\
\text { huge green areas, and therefore there } \\
\text { were not many roads." } \\
\text { Isabel, an 85-year-old woman who was } \\
\text { interviewed, mentioned that everything } \\
\text { was grown for self-consumption. She } \\
\text { even prepared composting with } \\
\text { leftovers. } \\
\text { Of the } 374 \text { questionnaires applied, 50\% } \\
\text { stated that they had participated in } \\
\text { cleaning activities performed by the } \\
\text { leaders or the municipal government; } \\
\text { however, stated that each time there is } \\
\text { less interest in some young people to } \\
\text { participate in the care of the lagoon. } \\
\text { "The young people prefer to sell the land } \\
\text { to keep it; they see tourism as an } \\
\text { opportunity to open a small section in } \\
\text { the lagoon in order to clean it." } \\
\text { Another interviewee, who was } 65 \text {, said } \\
\text { that agriculture is carried out depending } \\
\text { on cycles. "We do let the soil to rest, we } \\
\text { try to respect its times so that we do not } \\
\text { spoil it; however there are some people } \\
\text { who keep on cultivating the whole year. } \\
\text { A need is a need, particularly for food. } \\
\text { In the past we used to eat many things } \\
\text { the lagoon provided, but current } \\
\text { generations do not want to eat potatoes } \\
\text { or other seeds and we used to be very } \\
\text { healthy with the food we ate... now } \\
\text { people use chemical processes instead of } \\
\text { natural ones." } \\
\text { Celestino Lechuga, another interviewee } \\
\text { said "the way in which knowledge is } \\
\text { transmitted from generation to } \\
\text { generation is by speaking with our } \\
\text { children, because this is the only way it } \\
\text { can be done; however, I have also tried } \\
\text { to leave this legacy embodied in books, } \\
\text { giving researchers as yourselves the } \\
\text { information and support with photos and }\end{array}$ \\
\hline
\end{tabular}




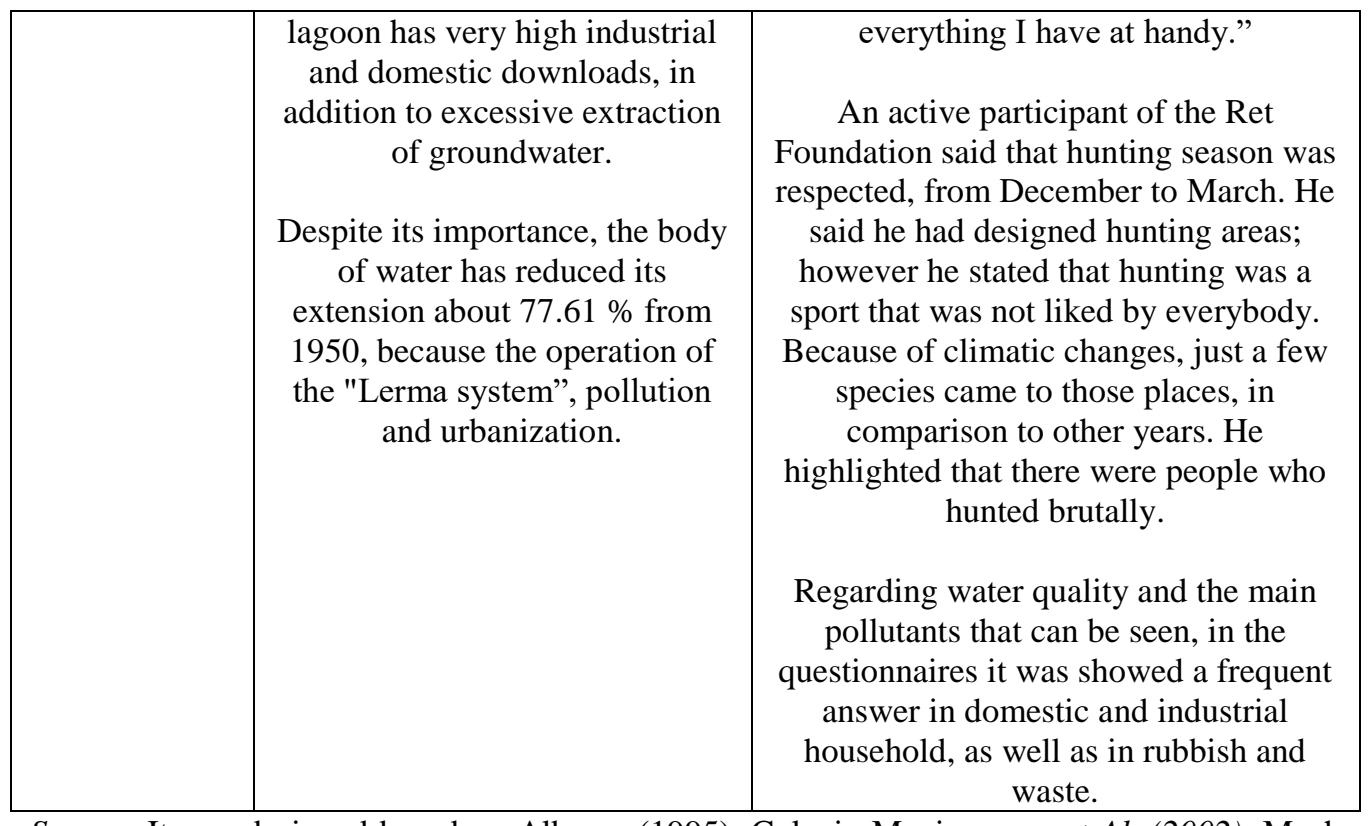

Source: It was designed based on Albores (1995), Colegio Mexiquense, et Al. (2002), Macho and Rosales (2010), Bastida, et al. (2012), RAMSAR.ORG (2014)

Table 5. Diagnosis of the Sub-System San Pedro Tultepec De Quiroga based on Attributes of Social Sustainability

\begin{tabular}{|c|c|c|}
\hline $\begin{array}{l}\text { Atributes of } \\
\text { Sustainability }\end{array}$ & Rational Evidence & Vernacular Evidence \\
\hline 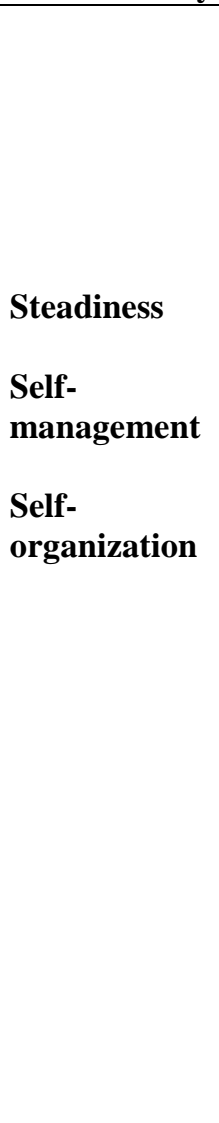 & $\begin{array}{c}\text { From a total of } 13.634 \\
\text { inhabitants, } 5,181 \text { are under } \\
\text { age and } 7,187 \text { are adults. } \\
695 \text { inhabitants are older } \\
\text { than } 60 \text { years old. } \\
\text { Form of land tenure is } \\
\text { community land: there are } \\
300 \text { community land owners. } \\
\text { The indigenous population } \\
\text { of San Pedro Tultepec is } 203 \\
\text { people who speak Nahuatl. } \\
484 \text { people who are } 15 \text { years } \\
\text { old or older are illiterate. } \\
\text { There are about } 80 \\
\text { inhabitants who are from } 6 \\
\text { to } 14 \text { years old who do not } \\
\text { go to school. } \\
\text { Sub-urbanized area: There } \\
\text { are } 2.383 \text { houses, of which } \\
2,253 \text { houses have sanitary } \\
\text { facilities, } 2.249 \text { have public } \\
\text { services and } 2.299 \text { have } \\
\text { electric light; } 119 \text { have } \\
\text { ground floor and } 124 \text { of } \\
\text { them have a single room.. }\end{array}$ & $\begin{array}{l}\text { There are few homes and businesses that } \\
\text { were built with sun-dried brick, others with } \\
\text { concrete and the workshops are made of } \\
\text { rustic foil. } \\
\text { In the questionnaires applied, it was noted } \\
\text { that } 82 \% \text { of women and children participate } \\
\text { in cleaning activities; } 75 \% \text { of children and } \\
\text { women are involved in workshops and } \\
\text { learning information. These figures are with } \\
\text { respect to families that are related to the } \\
\text { group of community land (there are } 300 \\
\text { community land owners). It should be noted } \\
\text { that at the time the questions were asked, } \\
\text { there were complaints since the leaders make } \\
\text { a poor distribution of the resources that are } \\
\text { granted by the municipal and state } \\
\text { government. } \\
\text { SEMARNAT, CONANP, as well as other } \\
\text { institutes and associations are mentioned that } \\
\text { give economic support to these areas. } \\
\text { With regard to the assemblies, the land } \\
\text { owners and their families observed that only } \\
\text { general topics such as cleaning and sale of } \\
\text { lands are discussed. } \\
\text { A land owner leader said that the economic }\end{array}$ \\
\hline
\end{tabular}




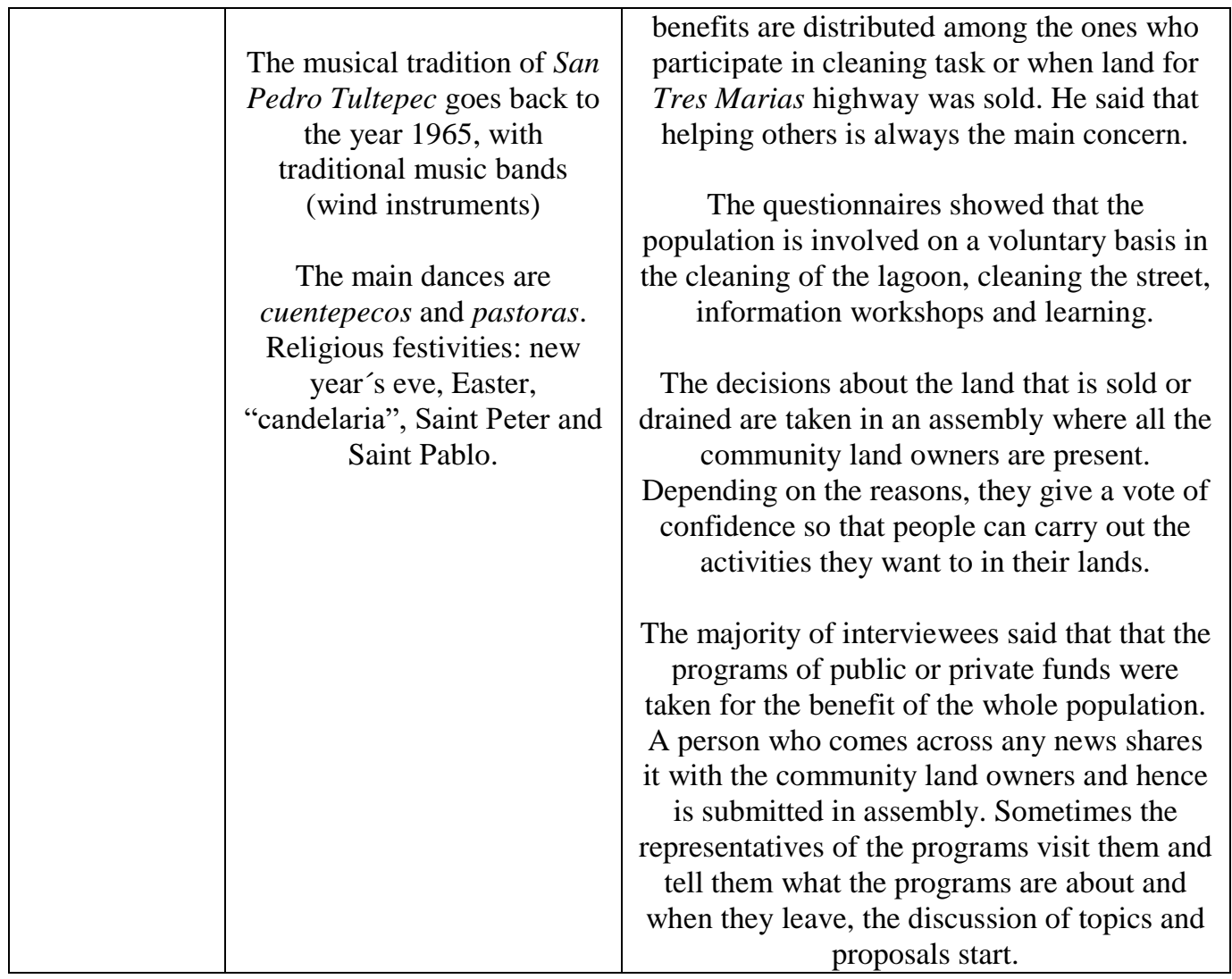

Source: It was designed based on Albores (1995), Colegio Mexiquense, et al. (2002), Macho and Rosales (2010), Bastida, et al. (2012), RAMSAR.ORG (2014)

Table 6. Diagnosis of the Sub-System San Pedro Tultepec De Quiroga based on Attribute of Cultural Sustainability

\begin{tabular}{|c|c|c|}
\hline $\begin{array}{c}\text { Atribute of } \\
\text { Sustainability }\end{array}$ & Rational Evidence & Vernacular Evidence \\
\hline Adaptability & $\begin{array}{l}\text { There are different institutions involved } \\
\text { in the training and workshops that are } \\
\text { offered in this community. } \\
\text { CONACULTA participates in the } \\
\text { rescue of the tule and the development } \\
\text { of art craft; SEMARNAT and } \\
\text { CONAGUA participate in preservation } \\
\text { and cleaning tasks, and ONG, Ramsar } \\
\text { and the Ret Foundation are involved } \\
\text { with the preservation of the wetland. } \\
\text { Considering the collective behavior } \\
\text { before the drying up of the lagoon, the } \\
\text { majority of families were dedicated to } \\
\text { making crafts of tule, from the } \\
\text { youngest to the oldest members of the } \\
\text { family. They were involved in cutting } \\
\text { the tule and the drying process, until the } \\
\text { tissue, which allowed the inhabitants } \\
\text { forge their identity as craftsmen. }\end{array}$ & $\begin{array}{l}\text { Household medicinal remedies most } \\
\text { commonly mentioned were made of } \\
\text { plants or animals. For example, the } \\
\text { salamander, which was used to cure } \\
\text { the anemia in young children; the } \\
\text { small fish called acociles to cure the } \\
\text { cough, among others. } \\
\text { There are still doctors who preserve } \\
\text { the traditional knowledge and cure } \\
\text { through it, as Don Lucas, "huesero". } \\
\text { If people break a foot or fall, they } \\
\text { can go with him. Doña Josefina is a } \\
\text { midwife who cures with teas } \\
\text { (according to an interview with the } \\
\text { altar server of the temple of } \\
\text { Calvario), encouraging the } \\
\text { preservation of natural and cultural } \\
\text { resources. }\end{array}$ \\
\hline
\end{tabular}




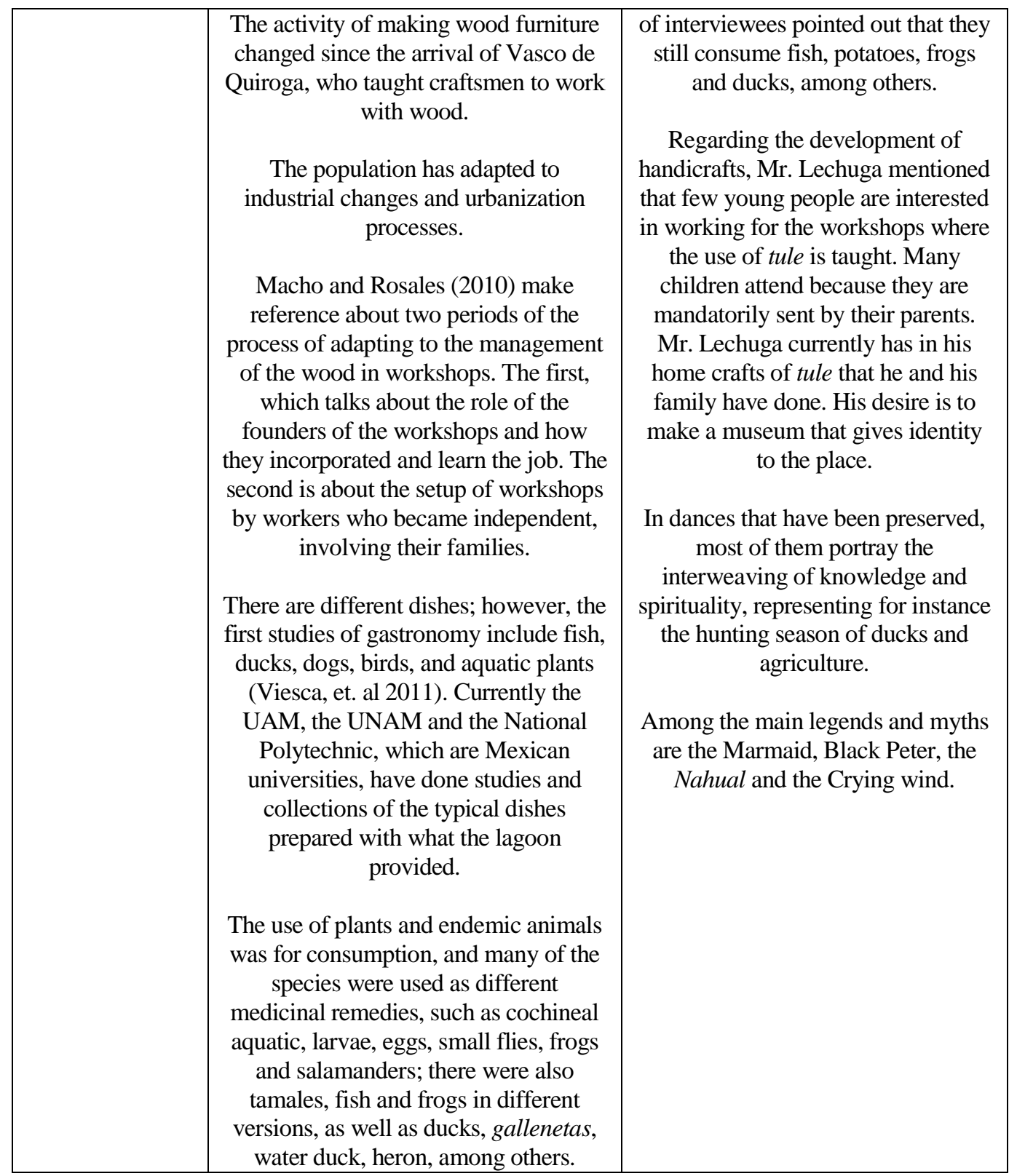

Source: It was designed based on Albores (1995), Colegio Mexiquense, et al. (2002), Macho and Rosales (2010), Bastida, et al. (2012), RAMSAR.ORG (2014) 
Table 7. Diagnosis of the Sub-System San Pedro Tultepec de Quiroga based on Attributes Of Economic Sustainablity

\begin{tabular}{|c|c|c|}
\hline $\begin{array}{l}\text { Atribute of } \\
\text { Sustainability }\end{array}$ & Rational Evidence & Vernacular Evidence \\
\hline $\begin{array}{l}\text { Productivity } \\
\text { Profitability } \\
\text { Viability }\end{array}$ & 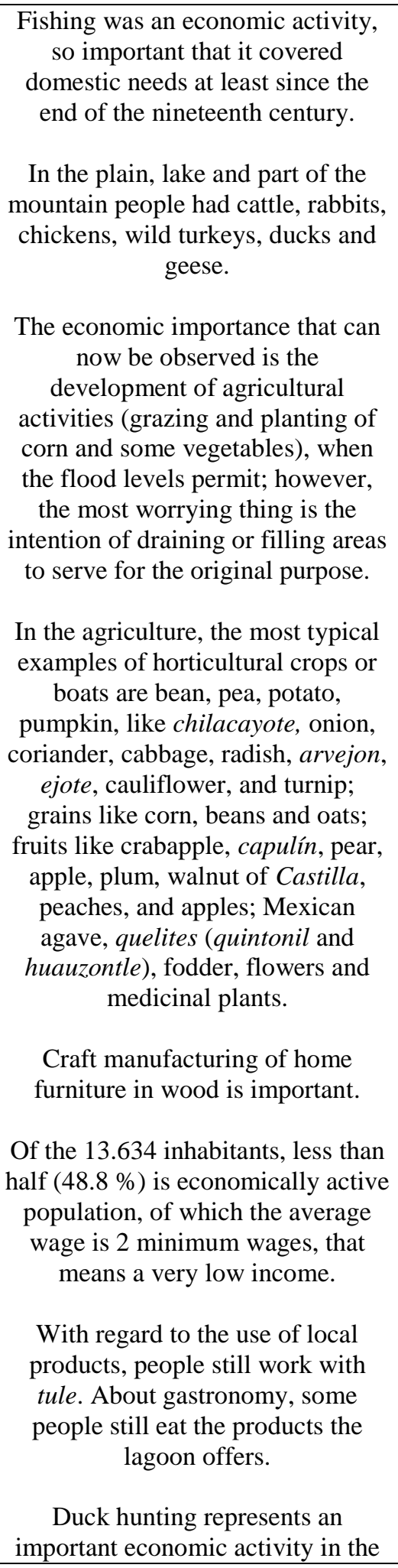 & 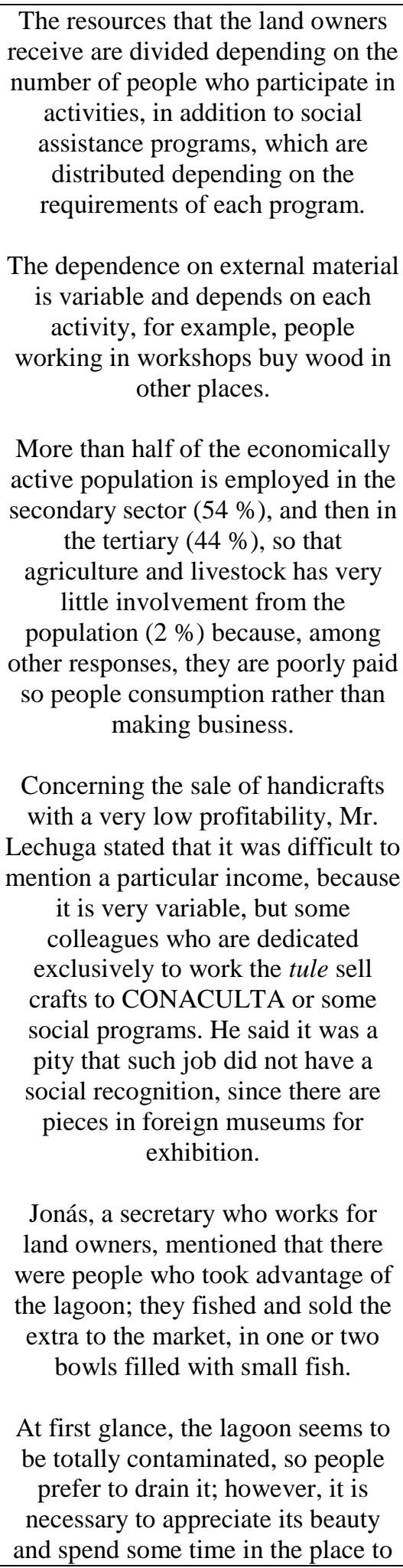 \\
\hline
\end{tabular}




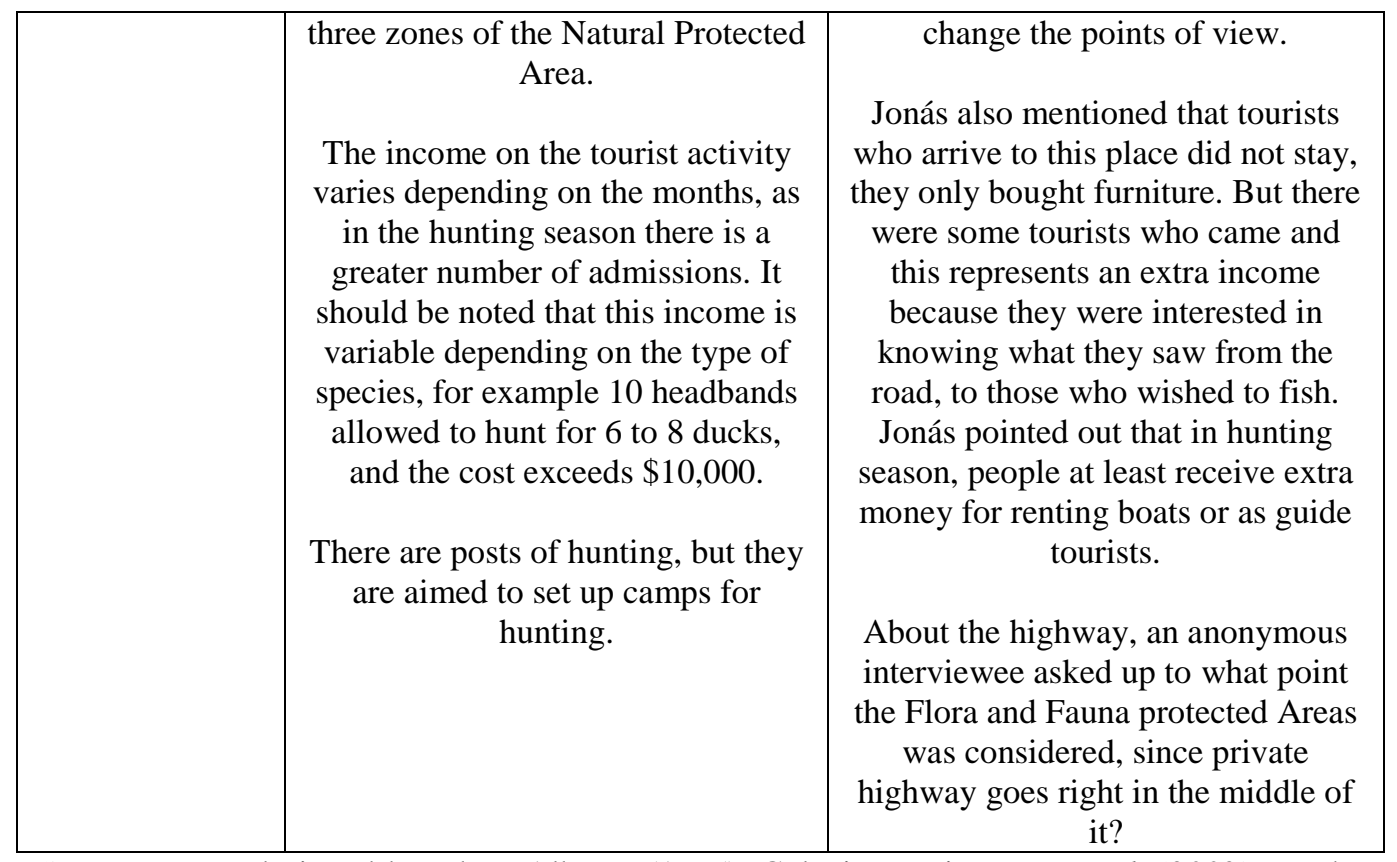

Source: It was designed based on Albores (1995), Colegio Mexiquense, et al. (2002), Macho and Rosales (2010), Viesca, et al. (2011), Bastida, et al. (2012), RAMSAR.ORG (2014)

Table 8. Diagnosis of the Sub-System San Pedro Tultepec de Quiroga from the Attribute of Technological Sustainability

\begin{tabular}{|c|c|c|}
\hline $\begin{array}{l}\text { Atribute of } \\
\text { Sustainability }\end{array}$ & Rational Evidence & Vernacular Evidence \\
\hline $\begin{array}{l}\text { Technological } \\
\text { adaptability }\end{array}$ & $\begin{array}{l}\text { In the words of Bastida, et. al, } \\
\text { (2012) "there are important } \\
\text { ethno-ecological matters, that is } \\
\text { to say, the knowledge that people } \\
\text { have about landscapes, the flora } \\
\text { and fauna from lake, among } \\
\text { other aspects, to keep it alive." } \\
\text { As time goes by, there have been } \\
\text { new technologies in hunting, } \\
\text { fishing and gathering of species } \\
\text { that existed before the drying of } \\
\text { the lagoon and that are still being } \\
\text { used, such as the fishing on } \\
\text { canoe and poultry (Albores 1995) } \\
\text { In addition to services such as } \\
\text { internet access, washing } \\
\text { machines, computers, and } \\
\text { television, among others, } \\
\text { machines in this community have } \\
\text { been updated for making } \\
\text { furniture and other items. }\end{array}$ & $\begin{array}{l}\text { The people who have seen the town } \\
\text { grow say that the changes have been } \\
\text { many. Before you could see carpenters } \\
\text { making wood carving, as their } \\
\text { grandparents were taught (and as Don } \\
\text { Vasco taught them). Now some have } \\
\text { already brought machines that help } \\
\text { making great products or even use } \\
\text { special tools to paint. } \\
\text { People still use the same techniques } \\
\text { for fishing, placing nets made by } \\
\text { themselves. It is not common to find } \\
\text { people using fishing canes. } \\
\text { According to an interview with the } \\
\text { altar server of the temple of Calvario, } \\
\text { he said that the only thing that people } \\
\text { retain is the technique to develop } \\
\text { crafts made of and people pretend to } \\
\text { teach their own kids, but it has not } \\
\text { been very favorable since children } \\
\text { think that is a lot of work and the } \\
\text { income is so low. }\end{array}$ \\
\hline
\end{tabular}

Source: It was designed based on Albores (1995), Colegio Mexiquense, et al. (2002), Macho y Rosales (2010), Bastida, et al. (2012), RAMSAR.ORG (2014) 
Table 9. Diagnosis of the Sub-System San Pedro Tultepec de Quiroga from the Attribute of Political-Institutional Sustainability

\begin{tabular}{|c|c|c|}
\hline $\begin{array}{l}\text { Atribute of } \\
\text { Sustainability }\end{array}$ & Rational Evidence & Vernacular Evidence \\
\hline $\begin{array}{l}\text { Institutional } \\
\text { viability }\end{array}$ & $\begin{array}{l}\text { The community is governed by } \\
\text { a commission of community } \\
\text { land owners, consisting of } 1.500 \\
\text { ha distributed among } 300 \\
\text { community land members. The } \\
\text { general assembly of land } \\
\text { owners is integrated by a } \\
\text { president, a commissioner and a } \\
\text { treasurer, in addition to } \\
\text { authorities as delegates, } \\
\text { considered from the local } \\
\text { perspective. Other actors who } \\
\text { have influence in the decisions } \\
\text { of the community are the } \\
\text { priests. } \\
\text { People participate in the } \\
\text { Program of Handling of the } \\
\text { Flora and fauna protected areas } \\
\text { from Lerma. In February, } 2004 \text {, } \\
\text { this program was declared as } \\
\text { RAMSAR site. This } \\
\text { commission states that if the } \\
\text { lagoon is handled sustainably, } \\
\text { tourism can bring great benefits. } \\
\text { The RET Foundation (Reuse } \\
\text { and Recycling of electronic } \\
\text { waste in favor of Education) is } \\
\text { in favor of stopping the } \\
\text { destruction of the lagoons, } \\
\text { through a campaign, against } \\
\text { hunting. They claim that the } \\
\text { lead from bullets is a toxic } \\
\text { element that can affect the } \\
\text { species living in the lagoon. }\end{array}$ & $\begin{array}{l}\text { A person wrote in one of the } \\
\text { questionnaires that in the official } \\
\text { page of the Ret Foundation people } \\
\text { can clearly see that the inhabitants are } \\
\text { dedicated to protecting the lagoon } \\
\text { and they know it is one of the } 150 \\
\text { most important places in America, } \\
\text { with more than 100,000 migratory } \\
\text { birds. } \\
\text { From the information gathered } \\
\text { through the questionnaires, about the } \\
\text { institutions that participate in the } \\
\text { handling and preservation of the } \\
\text { lagoon, just } 17 \% \text { knew that the } \\
\text { lagoon was protected, not only by } \\
\text { municipal and federal government, } \\
\text { but also by education institutions and } \\
\text { private ones. } \\
\text { Although people do not have much } \\
\text { different countries of the world, as } \\
\text { well as selling some in different } \\
\text { states of Mexico. } \\
\text { publishing company) implements } \\
\text { programs to promote crafts. Some } \\
\text { craftsmen of the community take part } \\
\text { some of them have attended some } \\
\text { events that famous people have } \\
\text { organized in order to raise } \\
\text { consciousness about the importance } \\
\text { of taking care of the lagoon. } \\
\text { Moreover, some small non-profit } \\
\text { companies are making use of social } \\
\text { networks, with the aim of } \\
\text { encouraging the communities } \\
\text { surrounding the lagoon to also take } \\
\text { care of it. }\end{array}$ \\
\hline
\end{tabular}

Source: It was designed adapted from Albores (1995), (2005), Colegio Mexiquense, et al. (2002), Macho and Rosales (2010), Bastida, et al. (2012), RAMSAR.ORG (2014)

\section{Discussion}

Relating the responses about rational and vernacular knowledge, it is possible to affirm that knowledge referring to the lake, inherited from the people's culture 
and lives, has been modified, due to the fact that previously a wide variety of species of plants were cultivated and consumed, such as potatoes, quelites, and huazontles. Among the traditional practices, which are still preserved by the older inhabitants and some young people, the use of tule to develop crafts, as well as the use of plants and animals as a traditional medicine, is still commonly developed. Typical dishes of the lake region offer a historical-cultural attraction for the region, which is a field of study for researchers from different countries.

The region stands out in the cultural-historical aspect because it shows evidence of the remote presence of ancient cultures, such as the Otomí or ñatho, and the Chichimeca-Matlatzinca. In the past there used to be a rich and complex culture around the water. All the water bodies that existed and are now temporarily dry were sacred places in ceremonies that were performed, and they could probably be recovered once the springs are recovered. The marshes have a great scenic value, due to the extension of the water mirrors and because of diverse aquatic vegetation and the permanent presence of dense populations of ducks, cattails and the banks.

Knowledge from generation to generation is still transferred by parents to children or grandchildren or by means of workshops, where some members of the community exchange knowledge with researchers, both domestic and foreign. Sometimes the youngest of the families attend the workshops to learn how to make tule handicrafts to create tiny animals. Across time, one of the activities that has been introduced and modified is the development of wooden furniture, both rustic and modern. Through this activity, inhabitants have gained national recognition.

Regarding the dances, there is a direct relationship between the lifestyle around the lake and the socio-cultural activities undertaken, primarily based on respect and the pursuit of harmony between man and natural resources, as well as to benefit from nature in daily activities. The dances are represented even in some festivities, like the Virgen de la Candelaria celebration (February 2nd), spring (March 21st), the "Petateros", the "Maringuillas" (from July to September), and St. Peter and St. Paul Day (June 29th), among others.

The musical tradition revolves around the activities on the lagoon and the population dynamics. This has been one of the main traditions that have survived. The community has music bands that participate in festivities; they are an icon of identity that is necessary to preserve, because of the feelings that are released.

On the other hand, the growth of road infrastructure in the area has generated an increase in land value, making it attractive to sell properties without draining or for cultivation purposes. Among the owners of land, there are different points of view. Younger inhabitants have somehow lost interest in preserving their land for their own use, due to the activity's low profitability.

From the various relationships observed between vernacular and rational knowledge, the following diagram was built; through this, it was possible to derive concrete actions that enable the community to achieve a harmonic tourism between both subsystems.

Based on this diagram (Figure 3), it is possible to observe that despite the process of draining, relevant interrelations are concentrated on historical and 
cultural backgrounds, which revolve around the Chimaliapan lagoon. This is how a harmonic tourism proposal is constructed to rescue and preserve the natural and cultural resources that currently exist.

Figure 3. Vernacular-rational Touristic planning of San Pedro Tultepec de Quiroga

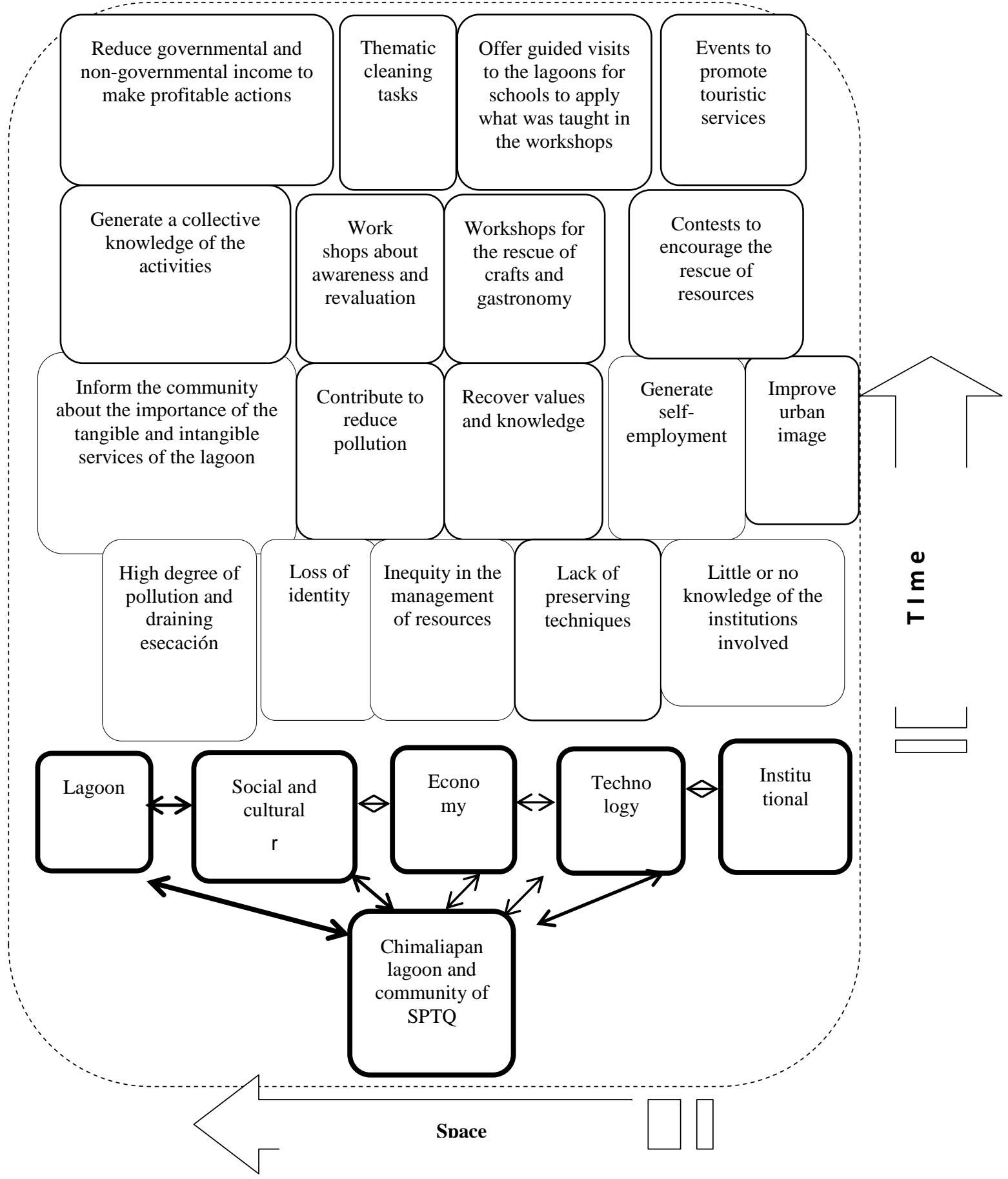


To foster harmonic tourism as an inclusive activity, which allows the rescuing and preserving of the lagoon, it is necessary to start disseminating information about tangible and intangible services offered by the lagoon to the community, in order to promote awareness about resources and benefits they have. It is recommendable to promote land owners' joint and collaborative work, which may lead to a collective consensus to support the project and share efforts that involve and benefit more members of the community. To achieve this, it is important to carry out activities and procedures included in the planning diagram, in addition to considering support from institutions.

There are necessary educational activities for the community regarding the role of tourism, which is seen as a choice of complementary economic productivity in the area, as well as to contribute to tourist routes consolidated in the region as part of a development strategy. Before promotion, it is mandatory to harmonize the subsystems through the improvement of the urban image, sanitation and health, coordinating the participation of groups in the area as well as the implementation of actions aimed at the preservation of environmental services.

\section{Final Considerations}

Based on the physical and socio-cultural characterization of the study area, the environmental problems facing the lagoon of Chimaliapan were pointed out. The biophysical subsystem shows a spatial-temporal alteration marked by historical facts that have been notorious, along with their co-adaptations with the anthropic sub-system, which has left its mark on the lifestyle of San Pedro Tultepec de Quiroga.

As part of the hommo-ecosystem Valley of Toluca (medium scale), geological, geomorphological, climatic, hydrological, soil and biological features correspond to processes that give rise to the Trans-Mexican volcanic belt and the high basin of the Lerma River. Likewise, socio-cultural conditions respond to policies and events that determine the change of land use, and activities prevailing in the region, such as the processes of industrialization and urbanization of the Toluca Valley and the extraction of water from the Lerma system to supply the cities of Mexico and Toluca.

At the local level, the hommo-ecosystem of San Pedro Tultepec de Quiroga, being an open system, also depends largely on its geographic surroundings. The Chimaliapan lagoon, which is part of a large wetland, is connected with two other bodies of water interconnected with the Lerma River. For this reason, there are issues outside the local hommo-ecosystem that still affect the area, such as the trail located in Ocoyoacac, the downloads from development and the treatment of textiles in Almoloya del Río, and municipal discharges from different pollutants into the Lerma River, among others.

The negative impacts that are facing the lagoon depend on the work that must be carried out from the anthropic subsystem, with special emphasis on the interconnectedness of society and public policies implemented to remedy and rescue, not just the lagoon, but also the whole lifestyle. 
This sub-systemic component has influence over other factors that give up structure to the subsystem, the influence of which takes place outside of the local hommo-ecosystem, as well as inside. On one hand, there is the influence of the economic activities, such as the chemical elements emanating from the manufacture of furniture, which is actually the base of the economy of the village; on the other hand, there are derivatives of household waste that go to the lagoon and cause damage to flora and fauna, natural resources that are later used as ingredients in traditional dishes, remedies and medicines and consumed by the population of San Pedro Tultepec de Quiroga and localities on the surrounding area.

A key factor that shows the relationship between politics, society and nature is the diversity of ages and interests of persons that participate in the commission of authorities, who make decisions about the use of the land and lagoon. Some young owners prefer draining the lagoon in order to build houses, while older owners give a higher environmental and social value to it.

Currently, the lagoon is for rent to an external investor who has control over it in the hunting season. This contract causes losses of flora and fauna of great ecological value, because of lead pollution from weapons discharges. However, the fact that the land is considered under communal ownership has allowed the lagoon to keep on, despite pollution and draining, since the elderly teach youngsters the value of the lagoon in their lives.

Regarding traditions, the interrelation between lagoon, culture, flora and fauna has historical importance and is related to dances and legends, gastronomy, hunting and wildlife. This significance causes an increased interest from land owners in community work to reduce lagoon pollution and find alternatives that will allow common interest to re-establish biological richness in these bodies of water. The alternative that the community finds is sustainable tourism, which aims to rescue the lagoon, traditions and customs, as well as to gain additional economic income.

It is very important that land owners work together to perform the cleaning and placement of protection barriers, so that during the rainy season people can avoid pollution from the San Juan river overflowing into the lagoon; this situation is linked to politics, since local authorities have ignored the community's demands for giving attention and helping them with these problems, as well as improving technology. Even though technology used in the lagoon activities is traditional, it is necessary to apply current technology outside the lagoon, in order to clean and purify water from the rivers that connect and flow to the lagoon.

To link the hommo-ecosystem with its exterior, it is observed that each weekend there are visitors coming to the place in order to acquire good quality furniture at low prices. However, a minority of the visitors are interested in visiting the lagoon itself, and they show little interest in tasting dishes or buying tule handcrafts. This phenomenon has influence over the decision-making process from the institutions that are in charge of the lagoon preservation; this gives greater empowerment to the economy derived from furniture production, fishing, flora and fauna collection and from the production of tule handicrafts. 
Around the lagoon, business activities exert influence over habits and customs, as well as their changes, and have consequences since the production of furniture requires the use of toxic and harmful substances for the lagoon and its species. It is clear that on weekends, families that used to visit the lagoon for recreational activities or cleanup tasks have modified their lifestyles, since these days people are busy selling furnitures.

Another change observed in the modifications and uses of the natural subsystem that has survived throughout history are the festivities, which allow the unification of the inhabitants of the village. There are traditional music bands that have been a characteristic of the place. History reports that in the past people worked for the lagoon and for the music bands. While celebrations constitute an element of integration between the hommo-ecosystem and its surroundings, it should also be an axis that allows the rescue of dances, like "Los Petateros", which is a graphic symbol of the use of the tule, including costumes and masks.

The above is a clear demonstration of how to analyze a sub-element of the complex system, with variables and influences over other sub-elements, showcasing that one relationship affects another one and so on. In the case of tourism, as a complementary activity, it can contribute to improving the conditions of the lagoon and to motivating land owners to carry out another type of tourism that could be more profitable.

\section{Conclusion}

When applying the model at San Pedro Tultepec de Quiroga, it is possible to affirm that this community, seen as a hommo-ecosystem, shows characteristics that can foster harmonic tourism as a tool to promote sustainable local development. In the studied community, the importance of information diffusion to the community regarding tangible and intangible services the lagoon offers was confirmed. This will promote awareness of the rescue of resources with those who provide tourism projects, in order to carry out a vernacular-rational tourism planning process, supported by the interests of the community surrounding the Chimaliapan lagoon. Thus, the community really focuses on the feeling of rescuing and preserving the lagoon, in addition to receiving economic benefits by developing this activity.

The importance of tourism has been one of the development priorities of governments around the world, at both national and local levels. However, it should not only give priority to monetary income, because as seen from the perspective of sustainability, tourism can help to rescue and to preserve natural and cultural resources of places where it is planned. That is why, from the construction of the theoretical - methodological model, it is possible to conclude that both approaches are different but interrelated, and so need to be framed independently.

From the theoretical-methodological context, the meaningful and dialectic aspect of research linked to complex systems is that the interrelationship between vernacular and rational knowledge is encouraged, thus allowing the construction and deconstruction of the initially established model. As time goes by, the study of 
the sub-elements in the subsystems modifies the sub-elements themselves, depending on the reality in which the model is applied.

From this scientific experience, the negative impacts that tourism left behind were identified due to inconsistencies and lack of considering the totality, as well as by linking it with each of their parts in moving forward. From there, it is important to mention that a system-based tourism is not linear as everything is interconnected, primarily when applied to the study of communities that have transcended by means of their knowledge.

In the studies with a complex systems approach, like in this case about a hommo-ecosystem proposal, environmental problems can be explained, interrelating the biophysical and anthropogenic sub-systems, with vernacular and rational knowledge. This approach could be an effective tool to design harmonic tourism projects, and thus enabling the rescue of local cultures.

\section{References}

Albores B (1995) Tules y sirenas. El impacto ecológico y cultural de la industrialización en el Alto Lerma. [Tules and sirens. The ecological and cultural impact of industrialization in the Alto Lerma] México: Colegio Mexiquense, A.C. y Gobierno del Estado de México.

Bastida M, Melo F, Oulhaj L (2012) Sistematización del concepto de desarrollo desde la perspectiva de los pueblos indígenas y sus prácticas: estudio de dos comunidades en México. [Systematization of the concept of development from the perspective of indigenous peoples and their practices: study of two communities in Mexico] México: Publicación en Internet.

Blázquez M, Cañada E, Murray I (2011) Búnker playa-sol. Conflictos derivados de la construcción de enclaves de capital transnacional turístico español en El Caribe y Centroamérica [Beach-sun bunker. Conflicts arising from the construction of enclaves of Spanish transnational tourism capital in the Caribbean and Central America]. Scripta Nova. Revista Electrónica de Geografía y Ciencias Sociales $\mathrm{XV}(368)$.

Ceballos G (2003) Ficha informativa de los humedales Ramsar (FIR). [Information sheet on Ramsar wetlands]Ramsar.org

CNET (2014) Avance del Panorama de la actividad turística en México. [Advance of the Panorama of the tourist activity in Mexico] No. 12 de enero a febrero. México: CNTE en colaboración con la Universidad Anáhuac.

Colegio Mexiquense, AC. COMECED, AC y Secretaria de Ecología (2002) Ciénagas de Lerma. Una caso ejemplar de desarrollo local. [Wetlands of Lerma. An exemplary case of local development] Xalapa: Gobierno del Estado de México.

CONANP (2011) Áreas Protegidas Decretadas. [Protected Areas Decreed] Consultado el 29 de septiembre de 2011. Retrieved from https://bit.ly/1xzLlfR.

RAMSAR.ORG (2007) Convención Relativa a los Humedales de Importancia Internacional. Ciénegas de Lerma. [Convention on Wetlands of International Importance. Wetlands of Lerma]. Retrieved from https://bit.ly/2mal607.

RAMSAR.ORG (2014) Manual de mejores prácticas para el diseño y la administración de centros de educación sobre los humedales. [Manual of best practices for the design and administration of education centers on wetlands]. Retrieved from https://bit.ly/1GtolVn. 
García R (2006) Sistemas complejos: conceptos, método y fundamentación epistemológica de la investigación interdisciplinaria. [Complex systems: concepts, method and epistemological foundation of interdisciplinary research] Barcelona: Gedisa.

INEGI (2010) Censo de Población y Vivienda 2010. [Population and housing census. 2010]Retrieved from https://bit.ly/1dUHp2c.

Macho E, Rosales R (2010) Empresarialidad femenina y redes sociales en San Pedro Tultepec de Quiroga, Estado de México. [Female entrepreneurship and social networks in San Pedro Tultepec de Quiroga, State of Mexico]. Retrieved from https://bit.ly/2md7Isj.

Morin E (2005) Mis demonios. [My demons] $2^{\mathrm{a}}$ ed. Barcelona: Kairos.

Norgaard R (1995) Development betrayed: the end of progress and a co-evolutionary revision of the future, 280 . Routdledge.

OMT (2002) El turismo y la reducción de la pobreza. [Tourism and poverty reduction] España: Organización Mundial del Turismo.

Palmas D, Serrano-Barquín RDC, Jiménez C, Gastón GGCJ (2011) Enfoques Teóricos para aplicaciones concretas: complejidad y turismo.[Theoretical approaches for specific applications: complexity and tourism] Gestión Turística,Enero-Junio, 99125.

Palmas D, Serrano-Barquín R, Gutiérrez CJ, Jiménez, CG, Favila Cisneros H (2014) Modelo teórico-metodológico para el estudio del turismo armónico y el desarrollo local.[Theoretical-methodological model for the study of harmonic tourism and local development] Investigaciones Turísticas 0(7): 23-46. Retrieved from https://bit.ly/2NL6LUE.

Segrado R, González A, Arroyo L, Palafox A (2010) El desarrollo de Cancún, analizado desde la Teoría de los Sistemas Complejos. [The development of Cancún, analyzed from the Theory of Complex Systems] Revista Gestión turística 14 Julio-diciembre. Chile.

SEMARNAT (2003) Información sobre incendios forestales. [Information about forest fires] Coordinación de Incendios Estatales, México: Secretaría de Medio Ambiente y Recursos Naturales, Delegación Estado de México.

SEMARNAT (2010) El medio ambiente en México 2009: en resumen. [The environment in Mexico 2009: in summary] México: Secretaría de Medio Ambiente y Recursos Naturales.

Serrano-Barquín R (2008) Hacia un modelo teórico-metodológico para el desarrollo, la sostenibilidad y el turismo. [Towards a theoretical-methodological model for development, sustainability and tourism] Revista Economía, sociedad y territorio VIII(26). México.

Viesca G, Carlos F, Somera F, Luis J, Contreras R, Tonatiuh A, Mendoza GM, Salazar QB (2011) El impacto de la desecación de la laguna de Lerma en la gastronomía lacustre de San Pedro Tultepec de Quiroga, Estado de México. [The impact of the desiccation of the Lerma lagoon on the lacustrine gastronomy of San Pedro Tultepec de Quiroga, State of Mexico] El Periplo Sustentable, Julio-Diciembre, 101-138. 
